\title{
Insulin-Like Growth Factor-I Is a Differentiation Factor for Postmitotic CNS Stem Cell-Derived Neuronal Precursors: Distinct Actions from Those of Brain-Derived Neurotrophic Factor
}

\author{
Yvan Arsenijevic and Samuel Weiss \\ Departments of Anatomy and Pharmacology and Therapeutics, University of Calgary Faculty of Medicine, Calgary, \\ Alberta, Canada T2N4N1
}

Insulin-like growth factor-I (IGF-I) has been reported previously to promote the proliferation, survival, and maturation of sympathetic neuroblasts, the genesis of retinal neurons, and the survival of CNS projection and motor neurons. Here we asked whether IGF-I could promote the in vitro differentiation of postmitotic mammalian CNS neuronal precursors derived from multipotent epidermal growth factor (EGF)-responsive stem cells. In the absence of IGF-I, virtually no neurons were present in cultured stem cell progeny, whereas IGF-I increased neuron number by eight- to 40 -fold. Brief exposures ( $2 \mathrm{hr}$ ) to IGF-I were sufficient to allow for neuronal differentiation without affecting proliferation or survival. IGF-I actions could be mimicked by insulin and IGF-II at concentrations that correspond to the pharmacology of the IGF-I receptor, the latter for which the mRNA was detected in undifferentiated stem cell progeny. Al- though ineffectual alone at low concentrations (10 nm) that would activate its own receptor, insulin was able to potentiate the actions of IGF-I by acting on mitotically active neural precursors. When neuronal precursor differentiation by IGF-I was examined in relation to brain-derived neurotrophic factor (BDNF), two important observations were made: (1) BDNF could potentiate the differentiating actions of IGF-I plus insulin, and (2) BDNF could act on a separate population of precursors that did not require IGF-I plus insulin for differentiation. Taken together, these results suggest that IGF-I and BDNF may act together or sequentially to promote neuronal precursor differentiation.

Key words: neurogenesis; insulin; insulin-like growth factor-l; brain-derived neurotrophic factor; in vitro differentiation; GABAergic neurons
Insulin-like growth factor-I (IGF-I), insulin, and their respective receptors are present throughout the CNS during embryogenesis, whereas at later stages of development IGF-I and IGF-I receptor mRNAs are localized discretely to certain neuronal populations (Petruzelli et al., 1986; Garofalo and Rosen, 1988; LeRoith et al., 1988; Bassas et al., 1989; Bondy et al., 1990, 1992; Bartlett et al., 1991; Bondy, 1991; Garcia-Segura et al., 1991; Devaskar et al., 1993; Kar et al., 1993). The presence of IGF-I and its receptor during development suggests that this factor may play a role in neurogenesis. This has been confirmed by reduced neuron numbers in vivo when IGF-I was eliminated by knock-out or reduced by antibody neutralization (Beck et al., 1995; Frade et al., 1996). Studies of the peripheral nervous system have shown that IGF-I is a mitogen for sympathetic neuroblasts and a stimulator of sympathetic neurite outgrowth (Mill et al., 1985; DiCicco-Bloom and Black, 1988; Caroni and Grandes, 1990) (for review, see Ishii, 1995; Zackenfels et al., 1995). In studies of CNS cells in vitro, IGF-I has been reported to increase neurogenesis from E5 pro-

\footnotetext{
Received Nov. 11, 1997; revised Dec. 24, 1997; accepted Jan. 6, 1998.

This work was supported by the Medical Research Council of Canada (MRC) Y.A. was the recipient of The Swiss Foundation for Medicine and Biology Fellowship. S.W. is an Alberta Heritage Foundation for Medical Research Scholar and an MRC Scientist. We thank Drs. Y. Sagot, D. van der Kooy, and A. Represa for the critical reading of an earlier version of this manuscript and Dr. Takuya Shimazaki for help with receptor detection.

Correspondence should be addressed to Dr. Samuel Weiss, Departments of Anatomy and Pharmacology and Therapeutics, University of Calgary Faculty of Medicine, 3330 Hospital Drive NW, Calgary, Alberta, Canada T2N4N1.

Dr. Arsenijevic's present address: Gene Therapy Center and Surgical Research Division, Centre Hospitalier Universitaire Vaudois, Lausanne University Medical School, Pavilion 3 and 4, 1011 Lausanne, Switzerland.

Copyright (C) 1998 Society for Neuroscience $\quad 0270-6474 / 98 / 182118-11 \$ 05.00 / 0$
}

liferating chick retinal neuroepithelial cells and to enhance survival of E10 rat neuroepithelial cells and embryonic spinal cord motor neurons (Drago et al., 1991; Hughes et al., 1993). In studies of postmitotic CNS populations, IGF-I stimulated choline acetyltransferase activity and increased enzyme immunoreactivity in septal and pontine neuronal cultures and increased dopamine uptake in cultures of ventral mesencephalon neurons (Knusel et al., 1990). In vivo, depending on the experimental condition used, IGF-I was found to rescue $29-94 \%$ of mouse and chick motor neurons after postnatal or embryonic axotomy (Hughes et al., 1993; Neff et al., 1993; Li et al., 1994). In summary, IGF-I appears to influence both early and late events in CNS neurogenesis; however, it remains unclear whether IGF-I can influence the differentiation of postmitotic neuronal precursors, e.g., acquisition of the neuronal phenotype independent of actions on survival and maturation.

We have isolated a self-renewing stem cell from the embryonic and adult mouse striatum that proliferates in response to epidermal growth factor (EGF) and produces progenitor cells that can differentiate into neurons, astrocytes, and oligodendrocytes (Reynolds and Weiss, 1992, 1996; Reynolds et al., 1992; Weiss et al., 1996). In vivo, the adult EGF-responsive cells participate in repopulation of the subependyma and can be mobilized to generate new neurons in the striatal parenchyma (Morshead et al., 1994; Craig et al., 1996). Despite the extensive characterization of the in vitro properties of these stem cells, the steps by which new neurons are produced are understood only partially. We have found that two types of stem cell-derived neuronal precursors, a bipotent (neuron/astrocyte-producing) and an unipotent (neuron only), are stimulated to divide by basic fibroblast growth factor 
(bFGF; Vescovi et al., 1993). Brain-derived neurotrophic factor (BDNF), on the other hand, enhances the differentiation but not the survival of these neuronal precursors (Ahmed et al., 1995). We suspect that other specific factors also contribute to this process and have asked whether IGF-I is one of these. Our findings suggest that IGF-I is indeed a differentiation factor for stem cell-derived neuronal precursors, with few or no actions on proliferation or survival. Moreover, our analyses suggest that IGF-I actions are distinct from those of BDNF in regard to the population/phenotype of precursors that they regulate.

\section{MATERIALS AND METHODS}

Primary culture and cell passaging. Striato-pallidum complexes were removed from 14-d-old CD1 mouse embryos (Charles River, Wilmington, MA) in PBS buffer containing $0.6 \%$ of glucose plus $50 \mathrm{U} / \mathrm{ml}$ penicillin and $50 \mathrm{mg} / \mathrm{ml}$ streptomycin, both from Life Technologies, Gaithersburg, MD). Tissue was dissociated mechanically with a firepolished pipette in serum-free medium composed of a 1:1 mixture of DMEM and F-12 nutrient (Life Technologies). Cells were grown in 40 $\mathrm{ml}$ of growth medium in Corning T75 flasks at a concentration of 200,000 cells $/ \mathrm{ml}$. The growth medium contained DMEM and F-12 nutrient (1:1), $0.6 \%$ glucose, $2 \mathrm{~mm}$ glutamine, $3 \mathrm{~mm}$ sodium bicarbonate, and $5 \mathrm{~mm}$ HEPES buffer [all from Sigma (St. Louis, MO), except glutamine, which was obtained from Life Technologies], $25 \mu \mathrm{g} / \mathrm{ml}$ insulin, $100 \mu \mathrm{g} / \mathrm{ml}$ transferrin, $20 \mathrm{nM}$ progesterone, $60 \mu \mathrm{M}$ putrescine, $30 \mathrm{nM}$ selenium chloride, and $20 \mathrm{ng} / \mathrm{ml} \mathrm{EGF}$ (Chiron, Emeryville, CA).

After $7 \mathrm{~d}$ in vitro (DIV), cells formed well developed floating clusters (spheres). To passage spheres, we pelleted 7 DIV spheres after centrifugation at $600 \times g$ for $5 \mathrm{~min}$, resuspended them in fresh medium, and mechanically dissociated them with a fire-polished Pasteur pipette. Single cells subsequently were seeded into EGF-containing medium in a Corning T75 flask at a concentration of 50,000 cells $/ \mathrm{ml}$. This procedure resulted in a second generation of spheres.

Differentiation of EGF-generated stem cell progeny. After 7 DIV the second generation of spheres was centrifuged and dissociated in EGFand insulin-free medium. Cells were plated onto poly-L-ornithine-coated coverslips in 24-well plates ( $2 \mathrm{~cm}^{2}$; Falcon, Oxnard, CA) at a density of 100,000 cells $/ \mathrm{ml}$, each well containing $1 \mathrm{ml}$ of medium with $1 \%$ fetal bovine serum (FBS). Human recombinant IGF-I, human recombinant IGF-II (both from Chiron), insulin (Sigma), and human BDNF (PeproTech, Rocky Hill, NJ) were added to the medium at the time of plating for an incubation period of 7 DIV, except when indicated otherwise.

Antibodies. Primary antibodies for indirect immunocytochemistry included a mouse monoclonal antibody to $\beta$-tubulin isotype III (final concentration 1:1000; Sigma), rabbit antiserum to glial fibrillary acidic protein (GFAP; 1:400; Biomedical Technologies, Stoughton, MA), and mouse monoclonal antibody to bromodeoxyuridine (1:5; Amersham, Arlington Heights, IL). The secondary antibodies (Jackson ImmunoResearch, West Grove, PA) used were as follows: rhodamine-conjugated affinity-purified goat antibody to mouse $\operatorname{IgG}(1: 200)$, fluoresceinconjugated affinity-purified goat antibody to mouse IgG (1:100), and aminomethyl-coumarin (AMCA)-conjugated affinity-purified goat antibody to rabbit $\operatorname{IgG}(1: 100)$.

Immunocytochemistry and cell counting. Indirect immunochemistry using secondary antibodies conjugated to rhodamine, fluorescein, or aminomethyl-coumarin (AMCA) was performed on cells $7 \mathrm{~d}$ after plating. Coverslips were fixed with $4 \%$ paraformaldehyde for $20 \mathrm{~min}$ and washed three times successively with PBS $(5 \mathrm{~min})$. For double labeling of $\beta$-tubulin and bromodeoxyuridine (BrdU), primary monoclonal antibody (anti- $\beta$-tubulin, 1:1000) was diluted in PBS containing 10\% normal goat serum and $0.3 \%$ Triton X-100. Coverslips were incubated for $2 \mathrm{hr}$ at $37^{\circ} \mathrm{C}$ and then were washed three times with PBS for 5 min each. Rhodamineconjugated secondary antibody was added (1:200), and the coverslips were incubated for $30 \mathrm{~min}$ at $37^{\circ} \mathrm{C}$. After three $5 \mathrm{~min}$ PBS washes, coverslips were incubated with primary antibody to $\operatorname{BrdU}(1: 5)$ for $2 \mathrm{hr}$ at $37^{\circ} \mathrm{C}$. All primary antibodies used in this study reached steady-state immunodetection after $2 \mathrm{hr}$ at $37^{\circ} \mathrm{C}$. The coverslips were washed again three times and incubated for $30 \mathrm{~min}$ with fluorescein-conjugated secondary antibody to mouse IgG (1:100). Coverslips were washed twice with PBS, and then Hoechst nuclear stain $(1 \mathrm{mg} / \mathrm{ml}$; Sigma) was added for $5 \mathrm{~min}$ at room temperature, followed by two more $5 \mathrm{~min}$ PBS rinses. A rapid water wash preceded the mounting of coverslips on glass slides with Fluorsave (Calbiochem, La Jolla, CA). For double labeling of
GFAP and $\beta$-tubulin, the primary antibodies were incubated at the same time, with the rest of the procedure remaining the same. Fluorescence was detected and photographed with a Nikon Optiphot photomicroscope.

Immunoreactive cells for $\beta$-tubulin, GFAP, or fluorescent nuclei from Hoechst labeling were counted over ten $20 \times$ fields. Homogeneous regions for cell density representative of the coverslip were chosen. Immunoreactive cells for $\beta$-tubulin were counted only when the nucleus was detectable on the $20 \times$ field investigated. After 7 DIV, the number of $\beta$-tubulin-immunoreactive neurons varied between culture preparations $-0-0.8 \%$ in control and $1.7-5.0 \%$ with $10 \mathrm{nM}$ IGF-I. Thus in some of the experiments, to ensure standardization with multiple comparisons, the number of neurons present after $7 \mathrm{DIV}$ in the presence of $10 \mathrm{~nm}$ IGF-I (15-50 $\beta$-tubulin-immunoreactive neurons within 600-900 cells) serves as $100 \%$, and the remaining data are presented as a percentage of $10 \mathrm{~nm}$ IGF-I. When $n$ was $<30$, the nonparametric Mann-Whitney $U$ test was used at the two-tailed level to distinguish the difference between experiments. Otherwise, unpaired Student's $t$ test was used. All results are expressed as a mean \pm SEM.

BrdU labeling and detection. To evaluate whether the production of neurons or astrocytes was associated with proliferation, we added BrdU (1 $\mu \mathrm{M}$; Sigma) at plating for 7 DIV. The presence of BrdU did not modify neuronal number nor total cell number. Cells were double-labeled for $\beta$-tubulin and BrdU, as described in Immunocytochemistry and Cell Counting. In each field $(\sim 70$ cells $)$ virtually no $\beta$-tubulinimmunoreactive cells were present in control conditions, whereas in the presence of $10 \mathrm{nM}$ IGF-I, one to four cells were $\beta$-tubulin-positive. Thus, at least 90-120 $\beta$-tubulin-immunoreactive cells per condition were counted in each independent experiment ( $n=3$ to 4$)$. From these data the percentage of double-immunoreactive cells for $\beta$-tubulin and BrdU was calculated.

Reverse transcription and PCR. Total RNA was extracted from EGFgenerated spheres and from cells plated in the presence or absence of 10 nM IGF-I for 7 DIV by single-phase phenol/guanidine isothiocyanate TRIzol reagent (BRL, Bethesda, MD). Cells were pelleted at $500 \times g$ and immediately frozen in liquid nitrogen. Then cells were lysed with TRIzol (200 $\mu \mathrm{l} / 10^{6}$ cells) on the day of reverse transcription. The organic and the aqueous phases were separated by the addition of 0.2 vol of chloroform and centrifuged at $3500 \times g$. Total RNA was precipitated from the aqueous phase with the addition of an equal volume of isopropanol at $-20^{\circ} \mathrm{C}$ overnight. Afterward, the dry pellet was dissolved in $4 \mathrm{M}$ guanidium thiocyanate, followed by the addition of $2 \mathrm{vol}$ of $95 \%$ ethanol and precipitated at $-20^{\circ} \mathrm{C}$ overnight. After centrif ugation, the pellet was resuspended in water for direct use in the reverse transcriptase reactions. The 260:280 ratio for all samples was between 1.6 and 2. First-strand cDNA was made with Superscript reverse transcriptase (BRL). Briefly, 1 $\mu \mathrm{g}$ of total RNA and $0.5 \mu \mathrm{g}$ oligo-dT were heated to $65^{\circ} \mathrm{C}$ and quickly chilled on ice. The annealed mRNA-oligo-dT complexes were incubated at $42^{\circ} \mathrm{C}$ for $75-90 \mathrm{~min}$ with $200 \mathrm{U}$ of reverse transcriptase in $20 \mu$ l total volume of (in mM) $0.5 \mathrm{dNTPs}, 50$ Tris, $\mathrm{pH} 8.3,75 \mathrm{KCl}, 3 \mathrm{MgCl}_{2}$, and 10 DTT. The reaction was heat-inactivated $\left(65^{\circ} \mathrm{C}\right.$ for $\left.15 \mathrm{~min}\right)$ and diluted to $50 \mu \mathrm{l}$ with water. The diluted reaction mix was used directly in PCR reactions. Primers specific for individual members of IGF receptor family were designed from published sequence data as follows: (1) IGF-I receptor $\alpha$-subunit, accession number U00182 (Mus musculus), the upstream (5') primer corresponds to position 129-148 (5'-TATCAGCAGCTGAAGCGCCT-3') and the downstream primer $\left(3^{\prime}\right)$ is complementary to position 590-571 (5'-GGTGGTCTTCTCACACATGG-3'), 464 bp amplified product; (2) IGF-II receptor, accession number L19500 (Mus musculus), the upstream $\left(5^{\prime}\right)$ primer corresponds to position 185-204 (5'CTGCTTGCTGGCCTTACTGC- $\left.3^{\prime}\right)$ and the downstream primer $\left(3^{\prime}\right)$ is complementary to position 566-547 (5'-CTTCAGGACCTTGCGCTGTG$\left.3^{\prime}\right), 382$ bp amplified product; (3) insulin receptor, accession number J05149 (Mus musculus), the upstream ( $\left.5^{\prime}\right)$ primer corresponds to position 3036-3055 (5'-TCCATCTTCTGTGTACGTGC-3') and the downstream primer ( $\left.3^{\prime}\right)$ is complementary to position 3782-3763 (5'-AGATAGCCTCCATCCATGAC-3'), 747 bp amplified product; (4) $\beta$-actin, accession number X03672 (Mus musculus), the upstream (5') primer corresponds to position 182-202 (5'-CGTGGGCCGCCCTAGGCACCA-3') and the downstream primer $\left(3^{\prime}\right)$ is complementary to position 424-404 (5'-TTGGCCTTAGGGTTCAGGGGG-3'), 243 bp amplified product. PCR analyses were performed in a final volume of $50 \mu \mathrm{l}$ containing $25 \mathrm{pmol}$ of each primer, $5 \mu \mathrm{l}$ of the reverse transcription reaction, $2.5 \mathrm{U}$ of Taq DNA polymerase $(0.5 \mu \mathrm{l})$, and (in $\mathrm{mM}$ ) 10 Tris- $\mathrm{HCl}, \mathrm{pH} 8.3,50 \mathrm{KCl}, 1.5 \mathrm{MgCl}_{2}$, and 0.2 each of the four dNTPs. After a denaturation step of $5 \mathrm{~min}$ at $97^{\circ} \mathrm{C}$, amplifications were started at $75^{\circ} \mathrm{C}$ (hot start) with $\mathrm{Taq}$ DNA polymerase for 30 cycles for insulin 
receptor and actin, and for 32 cycles for IGF-II receptor of $94^{\circ} \mathrm{C}$ for $45 \mathrm{sec}$, $x^{\circ} \mathrm{C} / 45 \mathrm{sec}$, and $72^{\circ} \mathrm{C} / 1 \mathrm{~min}, x$ being the annealing temperature at $60^{\circ} \mathrm{C}$ for IGF-II receptors and actin primer and at $59^{\circ} \mathrm{C}$ for insulin receptor primers. We used a two step PCR amplification for IGF-I receptor, beginning with a hot start. Thirty cycles of $94^{\circ} \mathrm{C}$ for $45 \mathrm{sec}$ and $68^{\circ} \mathrm{C}$ for 3 min were performed. Final products were analyzed on a $1.5 \%$ agarose gel. PCR amplification products for all receptors were excised out of the agarose gel and isolated by spin columns (Qiagen, Hilden, Germany). The purified fragments were sequenced. No genomic amplification was observed from any extracted RNA samples.

\section{RESULTS}

\section{IGF-I induces the appearance of neurons in stem cell progeny via an action at the IGF-I receptor}

We have shown previously that EGF-responsive stem cell progeny produce neurons, astrocytes, and oligodendrocytes when they are differentiated on a poly-ornithine substrate in vitro (Reynolds and Weiss, 1996). Here we asked whether specific activation of IGF-I receptors could increase the number of differentiated neurons. All experiments were performed without insulin in the medium to avoid its actions on insulin and/or IGF-I receptors. When dissociated cells derived from EGF-responsive stem cell progeny were cultured on poly-L-ornithine coverslips for $7 \mathrm{DIV}$ in the absence of insulin, virtually no or few cells immunoreactive for $\beta$-tubulin (an early neuronal marker) were present. However, neurons were generated in a dose-dependent manner when IGF-I and, to a lesser extent, IGF-II and insulin (Fig. $1 A$ ) were added to the culture medium. The increase in neuronal number ranged from eight- to 40-fold relative to control; the maximum number of neurons generated varied from 1.7 to $5 \%$ of total cell number. The half-maximal bioactivities $\left(\mathrm{ED}_{50}\right)$ of IGF-I, IGF-II, and insulin were $5.5 \pm 1.9,34.3 \pm 11.4$, and $262 \pm 84 \mathrm{~nm}$, respectively, corresponding to the pharmacology of the IGF-I receptor (IGFI $>$ IGF-II > insulin; LeRoith et al., 1993). This suggests that the generation of neurons at physiological concentrations occurred via an IGF-I receptor. The percentage of GFAP-immunoreactive cells (Fig. $1 B$ ) was not affected significantly by any of the growth factors, and the total cell number increased significantly only at supersaturating concentrations $(1 \mu \mathrm{M})$ of IGF-I or IGF-II (Fig. 1C).

To confirm that the generation of neurons by insulin and IGF-II occurred via their actions at IGF-I receptors, we examined whether IGF-I, IGF-II, and insulin had additive actions at the maximal effective dose of each factor. Coupled with its potency, a lack of additivity of either IGF-II or insulin with IGF-I would confirm that the action is mediated by the IGF-I receptor. The addition of $1 \mu \mathrm{M}$ IGF-II or $10 \mu \mathrm{M}$ insulin to $100 \mathrm{nM}$ IGF-I did not increase the production of neurons in comparison to $100 \mathrm{~nm}$ IGF-I alone (data not shown). In the next step of this initial characterization we performed reverse transcription (RT) of total cellular RNA (from EGF-generated stem cell progeny) and PCR for the IGF receptor family. The E14 whole brain served as control tissue. RT-PCR found that IGF-I, insulin, and IGF-II receptors were all expressed in stem cell progeny (Fig. 2). Taken together, these findings suggest that, despite the presence of all three receptor subtypes, the principal receptor mediating the growth factor-induced increases in neuronal number is the IGF-I receptor.

Although their numbers were not changed, IGF-I did induce a change in astrocyte morphology-10 nM IGF-I (or higher concentrations of insulin or IGF-II) induced a flattening and increased GFAP immunoreactivity (data not shown). These results confirmed previous results that used high concentrations of insu-
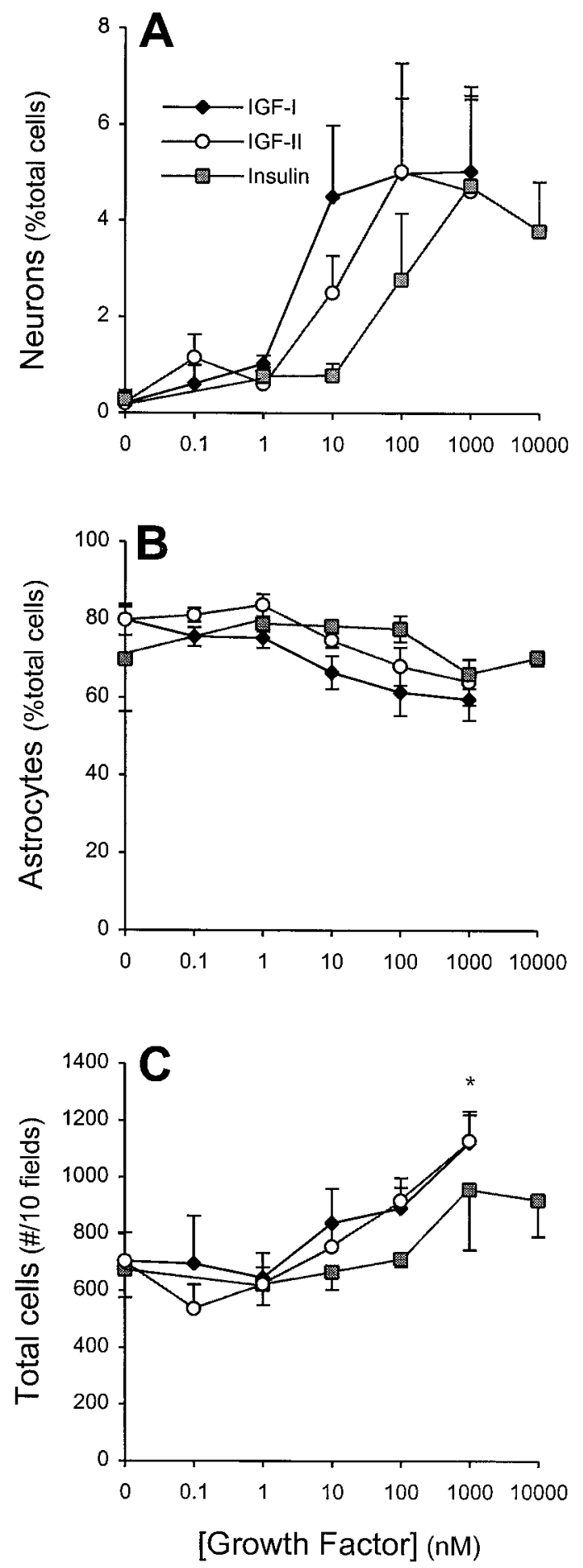

Figure 1. Effects of IGFs on neuron numbers in cultures of EGFgenerated precursors. $A$, Increasing concentrations of IGF-I, IGF-II, and insulin induced a dose-dependent increase in neuron ( $\beta$-tubulinimmunoreactive) production, expressed as a percentage of total cells derived from EGF-generated spheres. The rank order of potency, IGFI > IGF-II > insulin, is characteristic of IGF-I receptor pharmacology (LeRoith et al., 1993) (see Results for further discussion). Growth factors were added at plating and were present for the entire culture period. Under the identical experimental conditions the percentages of astrocytes (GFAP-immunoreactive $(B)$ and total cell number $(C)$ were not affected significantly, other than total cell numbers at supersaturating $(1 \mu \mathrm{M})$ concentrations of IGF-I or IGF-II. Data represent the mean \pm SEM of four independent cultures; * $p<0.05$. 


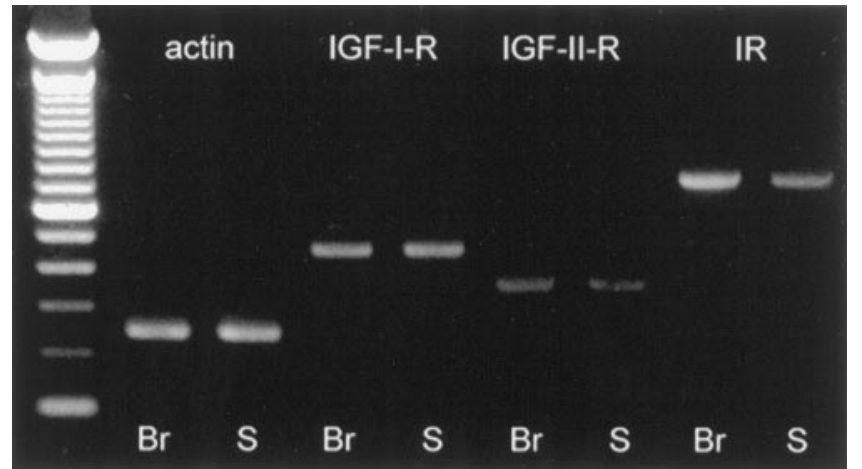

Figure 2. Detection of IGF receptor subtypes in embryonic brain and EGF-generated spheres. Reverse transcription and PCR of total RNA extracted revealed that IGF-I, insulin, and IGF-II receptor mRNA are present in the E14 brain $(\mathrm{Br})$ and in the EGF-generated spheres of undifferentiated precursors $(S)$. First-strand cDNA was amplified by using specific primers, as described in Materials and Methods. The ladder is the $100 \mathrm{bp}$ ladder (from BRL). Amplified products were run out on a $1.5 \%$ agarose/Tris-acetate-EDTA gel and visualized with ethidium bromide. No genomic amplification was observed from any extracted RNA samples.

Table 1. Numbers of neurons generated in response to IGF-I in low density cultures of EGF-generated precursors

\begin{tabular}{lcl}
{$[\mathrm{IGF}-\mathrm{I}](\mathrm{nM})$} & $\begin{array}{l}\text { Neuron } \\
\text { (number/30 } \\
\text { fields) }\end{array}$ & $\begin{array}{l}\text { Total cells } \\
\text { (number/30 } \\
\text { fields) }\end{array}$ \\
\hline 0 & $4.3 \pm 1.4$ & $220 \pm 36.8$ \\
10 & $11.5 \pm 2.4^{*}$ & $193 \pm 51.3$ \\
100 & $12.8 \pm 1.7^{* *}$ & $221 \pm 51.6$
\end{tabular}

EGF-generated spheres were dissociated and plated at 50 cells $/ \mathrm{mm}^{2}$. Data are the mean \pm SEM for four independent culture experiments. ${ }^{*} p<0.05 ;{ }^{* *} p<0.01$, in comparison to control (0 IGF-I).

lin (Toran-Allerand et al., 1991). These findings raise the possibility that the action of IGF-I on neuron production could be an indirect effect via the maturation of astrocytes. To address this issue, we reexamined IGF-I actions at a lower cell density. Thus, the actions of 10 and $100 \mathrm{~nm}$ IGF-I were examined on 50 EGFgenerated cells $/ \mathrm{mm}^{2}$ (rather than 500 cells $/ \mathrm{mm}^{2}$ in standard conditions). Under these experimental conditions IGF-I remained a potent and effective enhancer of neuronal production (Table 1). Again, total cell number did not vary. However, the basal neuron number (in the absence of IGF-I) was greater in low-density experiments. A putative unidentified inhibitor for neuronal differentiation may be effective only at higher density and attests to the presence of multiple factors secreted by cells that could interact in neuronal differentiation. Nevertheless, taken together these results suggest that the numbers of neurons are increased by IGF-I activation of its receptors on neuronal precursors.

\section{IGF-I-induced increases in neuronal number are attributable to differentiation and not to proliferation nor survival of neuronal precursors}

In control conditions virtually no $(0-0.8 \%) \quad \beta$-tubulinimmunoreactive cells were observed in a field of $\sim 70$ cells, whereas in the presence of $10 \mathrm{~nm}$ IGF-I one to four cells (1.7$5.0 \%)$ were $\beta$-tubulin-positive. When 10 fields were counted in three independent cultures, $10 \mathrm{~nm}$ IGF-I induced a significant increase in neuron number (Fig. $3 A$ ). The increased neuron number after IGF-I treatment could be attributable to one of several possible actions: (1) the proliferation of neuronal precur-
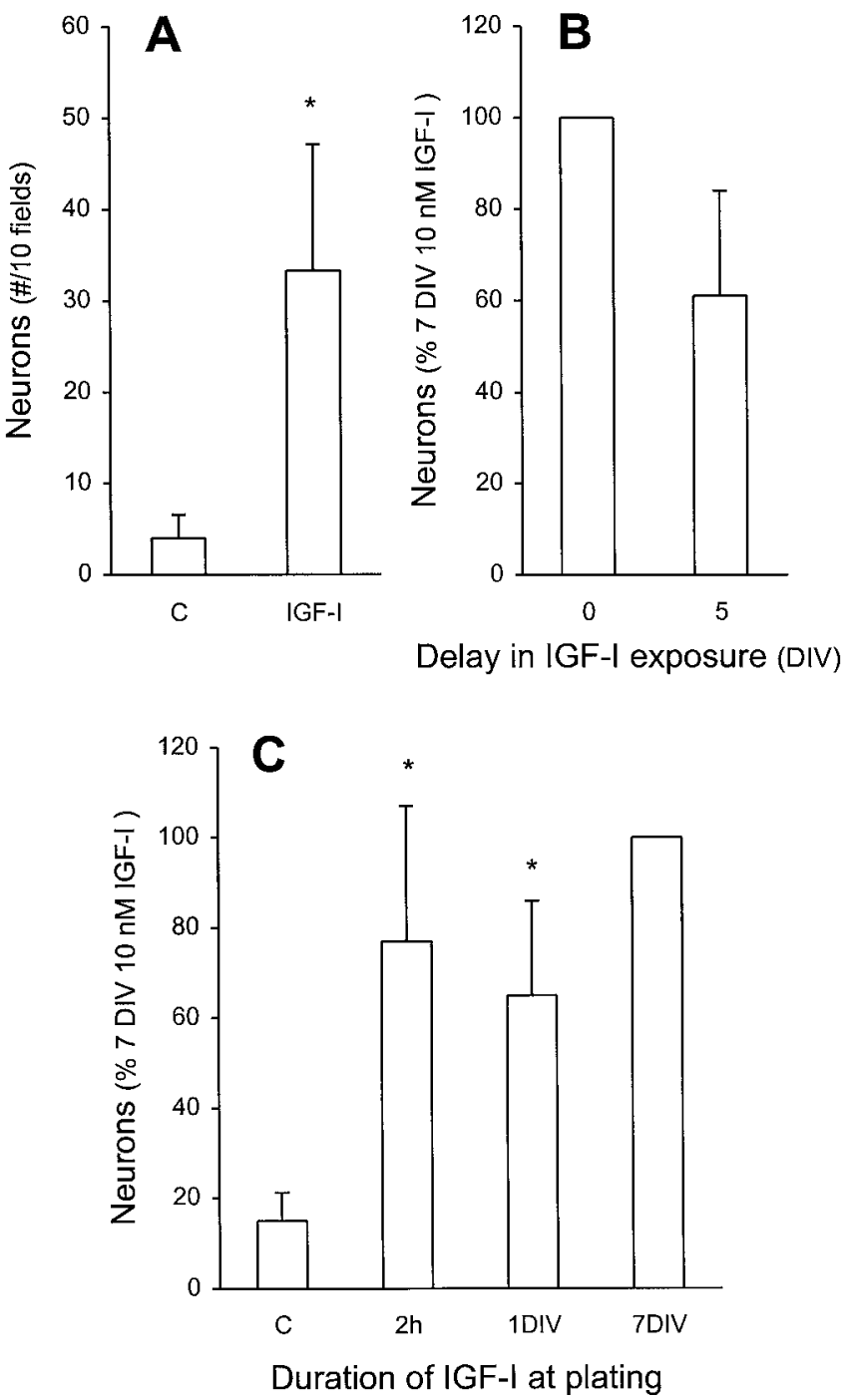

Figure 3. IGF-I increases neuron number without an apparent survival action. A, EGF-generated precursors were cultured in the absence or presence of $10 \mathrm{~nm}$ IGF-I for 7 DIV. The total number of neurons in 10 fields (total of 600-900 cells) was determined. In subsequent experiments, to ensure standardization with multiple comparisons, the number of neurons present after 7 DIV in the presence of 10 nM IGF-I (15-50 $\beta$-tubulin-immunoreactive neurons within 600-900 cells) serves as $100 \%$. $* p<0.05$ compared with control. $B$, A 5 d delay (from plating) in exposure of precursors to $10 \mathrm{nM}$ IGF-I yielded neuron numbers that were not significantly different from a 7 DIV exposure starting at plating. $C$, Brief exposure to IGF-I was sufficient to induce neuronal differentiation. IGF-I (10 nM) was added for $2 \mathrm{hr}(2 h)$ at plating or for $1 \mathrm{DIV}$, followed by extensive washing and a total 7 DIV incubation, and then compared with control (*significantly different, $p<0.05$ ) or to a 7 DIV exposure (not significantly different). All data represent the mean \pm SEM of three independent culture experiments.

sors, (2) the survival of neuronal precursors, (3) the survival of postmitotic neurons, or (4) the differentiation of neuronal precursors into neurons. These different possibilities were examined in the following experiments.

Studies of PNS neuroblasts have demonstrated that IGF-Iinduced increases in neuronal numbers are attributable to a mitogenic action. To determine whether the increased number of neurons caused by IGF-I occurs via proliferation of precursors, we included the thymidine analog $\operatorname{BrdU}(1 \mu \mathrm{M})$ in cultures of 

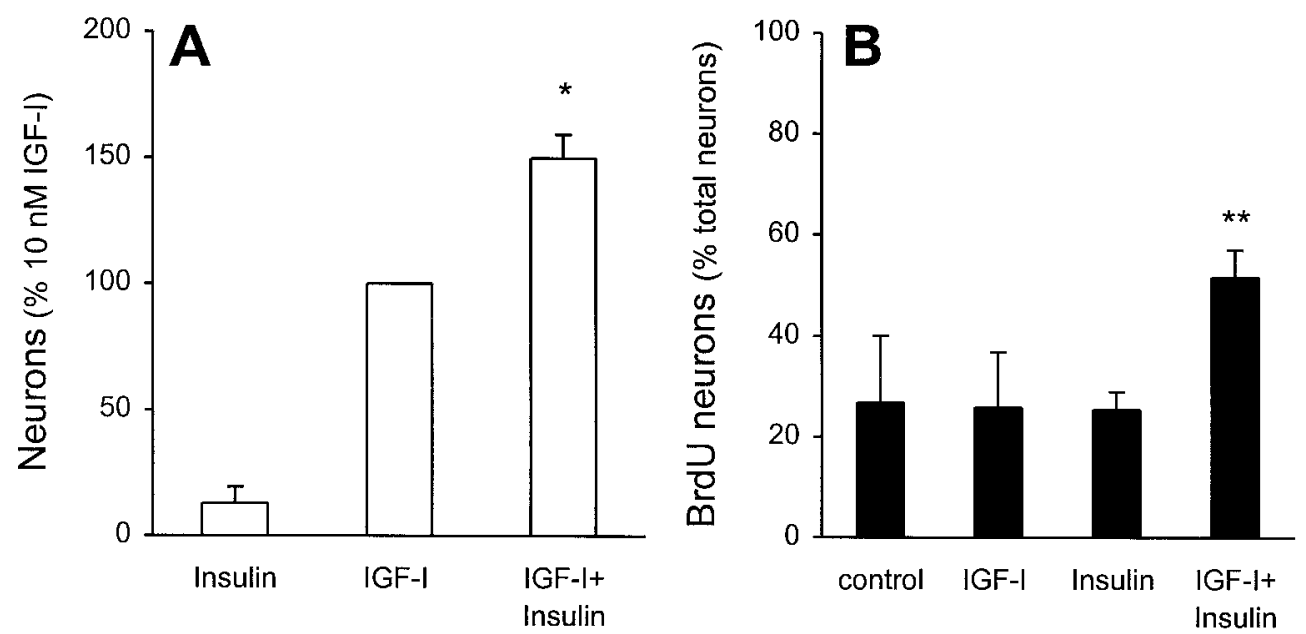

Figure 4. IGF-I and insulin cooperate to produce enhanced numbers of neurons. EGF-generated precursors were cultured with $1 \mu \mathrm{M}$ BrdU in the absence or presence of $10 \mathrm{~nm}$ insulin, $10 \mathrm{~nm}$ IGF-I, or the two combined, for $7 \mathrm{DIV}$. $A$, With the numbers of $\beta$-tubulin-immunoreactive neurons produced by 7 DIV of $10 \mathrm{~nm}$ IGF-I serving as 100\% (see legend to Fig. 3 and Materials and Methods for details), the combined actions of $10 \mathrm{~nm}$ IGF-I plus 10 nM insulin are found to be more than additive $\left({ }^{*} p<0.05 ; n=4\right.$ independent cultures). $B$, In each condition, $100 \beta$-tubulin-immunoreactive neurons were examined for incorporation of BrdU, and the percentage of double-labeled cells was calculated. The combined actions of $10 \mathrm{~nm}$ IGF-I plus $10 \mathrm{~nm}$ insulin result in a twofold increase in newly generated neurons ( ${ }^{* *} p<0.01$ relative to control or insulin; $p<0.05$ relative to IGF-I; $n=4$ independent cultures). Taken together, these data suggest that increased neuronal numbers caused by combined insulin plus IGF-I is attributable to actions on mitotically active neuronal precursors.

stem cell progeny for 7 DIV both in the absence or presence of 10 nM IGF-I. Because control studies indicated that BrdUimmunopositive neurons constituted $10-20 \%$ of the total $\beta$-tubulin-positive neurons, additional extensive counting was performed for all BrdU double-labeling experiments. Thus, in each independent experiment $(n=3$ and in each condition therein) at least 90-120 $\beta$-tubulin-immunoreactive cells were counted as being either single- or double-labeled. From this data the percentage of double-immunoreactive cells for $\beta$-tubulin and BrdU was calculated. After 7 DIV in the absence of IGF-I, a small number of neurons $(18.6 \pm 0.6 \%)$ incorporated BrdU. After 7 DIV with $10 \mathrm{nM}$ IGF-I, a similarly small $(11.3 \pm 4.4 \%$, not significantly different) number of the neurons was BrdUimmunoreactive. If the increased numbers of neurons caused by IGF-I were a result of neuronal precursor proliferation, one would expect a significant increase in the percentage of $\beta$-tubulinimmunoreactive neurons that incorporate BrdU, corresponding to the number of newly generated neurons. However, this was not the case. Thus, it is apparent that the increased numbers of neurons cannot be attributable to proliferation; therefore, IGF-I does not have a mitogenic action on stem cell-generated neuronal precursors.

The increasing number of neurons induced by IGF-I could be attributable to an enhanced survival of neuronal precursors that then could differentiate spontaneously. We define survival to be a dependence that would require the continued presence of the factor throughout the culture period. Withdrawal of the factor would result in death. Delay in administering the factor should result in a dramatic and significant attenuation, relative to continued presence. This was tested as follows. We delayed the addition of IGF-I for $5 \mathrm{~d}$ and counted the neuron number at 7 DIV. Under these conditions neuronal production was slightly, but not significantly ( $p=0.19$; Fig. $3 B$ ), reduced relative to a 7 DIV administration. Then we tested the possibility that IGF-I acts as a survival factor for postmitotic neurons. This goal was achieved by short-term exposures of IGF-I at plating. Then the culture was maintained until 7 DIV. If IGF-I is a survival factor for neurons, we expected a significant reduction in neuron number after 7 DIV. Exposures to IGF-I for as little as $2 \mathrm{hr}(p=0.44)$ or 1 DIV ( $p=0.19$ ) essentially mimicked the action of IGF-I when it was present throughout the culture period (Fig. 3C). It is particularly noteworthy that a $2 \mathrm{hr}$ exposure produced an equivalent number of $\beta$-tubulin-immunoreactive cells as a 7 DIV exposure. Thus, these results suggest that the increased number of neurons produced by IGF-I is not an action on the survival of postmitotic neuronal precursors or neurons but rather an induction of differentiation.

\section{IGF-I and insulin are synergized to produce neurons}

Although the results of our study clearly point to an action of IGF-I at its receptor for inducing neuronal differentiation, the presence of receptors for both insulin and IGF-II (see Fig. 2) prompted us to examine whether the activation of these receptors could modulate the IGF-I response. Given our observation that short exposure $(2 \mathrm{hr}$ ) to IGF-I was a sufficient stimulus for differentiation, we performed these and all subsequent experiments with an additional insulin-free prewash (see Materials and Methods) during the dissociation procedure to ensure that no activation occurred before plating. To examine the putative interactions among ligands, we used $10 \mathrm{~nm}$ concentrations of both IGF-I and insulin to allow for maximal stimulation of each respective receptor without cross-reacting with the other (LeRoith et al., 1993). When stem cell progeny were exposed to $10 \mathrm{~nm}$ insulin alone for $7 \mathrm{DIV}$, a small number of neurons was generated (Fig. 4A). This result is in accordance with those of Figure 1. IGF-I (10 nM) increased neuron production by approximately eightfold. When insulin and IGF-I were combined, the resultant number of neurons was $37 \%(p=0.02)$ greater than the additive effect of the both factors alone, although total cell number did not change (IGF-I $=608 \pm 64$ cells/10 fields; IGF-I plus insulin $=642 \pm 44$ cells $/ 10$ fields). This suggests that insulin and IGF-I have synergistic actions on neuronal production. When 

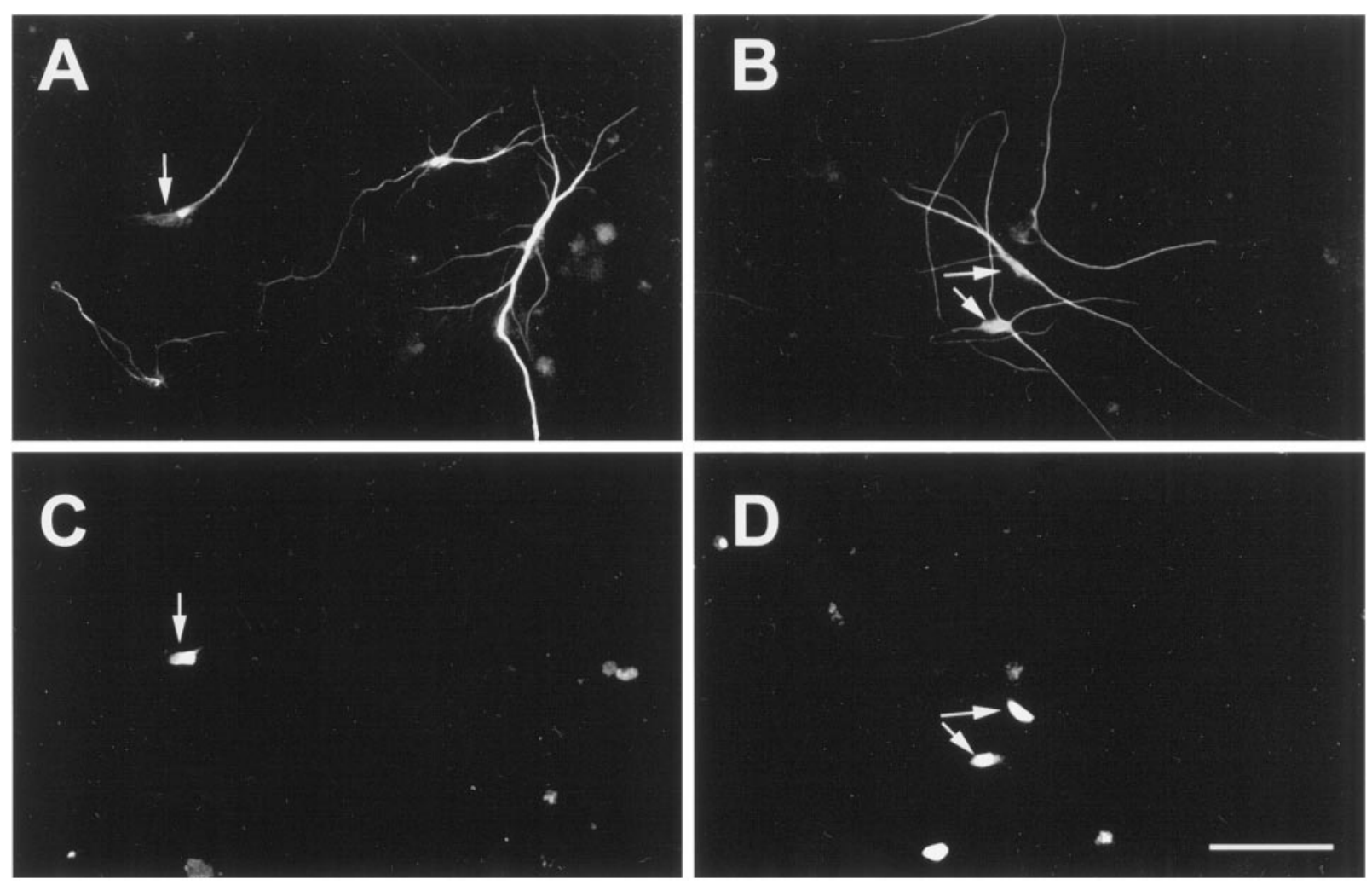

Figure 5. Dual labeling for $\beta$-tubulin and BrdU provides evidence for newly generated neurons. EGF-generated spheres were dissociated and plated for 7 DIV with $1 \mu \mathrm{M}$ BrdU in the presence of $10 \mathrm{~nm}$ IGF-I $(A, C)$ or $10 \mathrm{~nm}$ IGF-I plus $10 \mathrm{~nm}$ insulin $(B, D)$. Cells were dual-labeled for $\beta$-tubulin $(A$, $B)$ and $\operatorname{BrdU}(C, D)$ immunoreactivity. Arrows illustrate $\beta$-tubulin-immunoreactive neurons that had incorporated BrdU. Despite the use of two monoclonal antibodies, our incubation procedure did not generate nonspecific overlap, as demonstrated by both coincident and noncoincident immunolabeling (with steady-state immunofluorescent intensity) in the same field (see Materials and Methods for details). Scale bar, $20 \mu \mathrm{m}$.

IGF-II (10 nM) was coincubated with either insulin or IGF-I, no synergistic actions were observed.

We next asked whether the neuronal production generated by the coincubation of insulin and IGF-I was attributable to the proliferation of a neuronal precursor. In each condition 100 $\beta$-tubulin-immunoreactive neurons were examined for the incorporation of BrdU, and the percentage of double-labeled cells was calculated. If the $37 \%$ increase in total neurons caused by the presence of insulin is a result of proliferation, this would translate into $\sim 27 \%$ of additional (to IGF-I) BrdU/ $\beta$-tubulin doublelabeled cells (indicating that all additional neurons had undergone mitosis before differentiation). We found that the combined actions of $10 \mathrm{nM}$ IGF-I plus $10 \mathrm{~nm}$ insulin resulted in an additional $25 \%$ in the population of BrdU/ $\beta$-tubulin double-labeled cells $(\mathrm{IGF}-\mathrm{I}=27 \pm 13 \%$; IGF-I plus insulin $=52 \pm 5 \%$; Fig. $4 B$ ). These findings suggest that the more than additive numbers of neurons observed when IGF-I and insulin were coincubated likely are derived from a mitotically active precursor population. Figure 5 demonstrates that, despite the use of two monoclonal antibodies (against $\beta$-tubulin and BrdU), our incubation procedure did not generate nonspecific overlap, as demonstrated by both coincident and noncoincident immunolabeling (with steady-state immunofluorescent intensity) in the same field.

\section{IGF-I and BDNF act on two populations of undifferentiated neuronal precursors}

We have demonstrated previously that BDNF is also a differentiation factor for stem cell-derived neuronal precursors. Those experiments were performed with high $(4 \mu \mathrm{M})$ insulin. Interest- ingly, the actions of BDNF required $>5 \mathrm{~d}$ to develop, in comparison to IGF-I actions that required only short incubation periods (see Fig. 3C). Thus, we sought to determine whether IGF-I and BDNF actions could be distinguished. Dissociated EGF-generated precursors were cultured in the absence of insulin or IGF-I and in the presence of increasing concentrations of BDNF. BDNF induced a dose-dependent (Fig. 6A) increase in neuronal numbers; total cell number was unaffected (data not shown). At saturating concentrations (50 ng/ml), BDNF induced a significant three- to fourfold increase in neuronal number (Fig. $6 B)$. In eight independent culture experiments we compared the maximal efficacies of BDNF and IGF-I. Maximal efficacy of BDNF was approximately one-third that of IGF-I.

These results suggested three possibilities. BDNF might act on the same precursors as IGF-I (plus insulin), on a distinct population, or on both. This was studied in two ways. First, we coincubated low concentrations of insulin and IGF-I (both at 1 $\mathrm{nM}$ ), which were ineffectual alone (Fig. $6 C$ ), and this resulted in a combined action that was $\sim 20 \%$ of that produced by $10 \mathrm{~nm}$ IGF-I alone. When $50 \mathrm{ng} / \mathrm{ml}$ of BDNF was added to $1 \mathrm{~nm} \mathrm{IGF-I} \mathrm{plus}$ insulin, the resultant production was not significantly different from $10 \mathrm{~nm}$ IGF-I. Furthermore, this combined response was much more than additive. Total cell numbers were unaffected (data not shown). If we subtract the BDNF action, the resultant stimulation by IGF-I plus insulin is increased by 3.85 -fold $(p<$ $0.05)$, suggesting that BDNF can potentiate the actions of IGF-I plus insulin. Yet these results cannot exclude an action of BDNF on a different population of cells. To test this, we exposed stem 
cell progeny to maximal concentrations of IGF-I plus insulin $(10$ nM each) or BDNF (50 ng/ml) or all three combined (Fig. 6D). When all three were coincubated, the resultant neuron number was completely additive, but the total cell number was not signif-
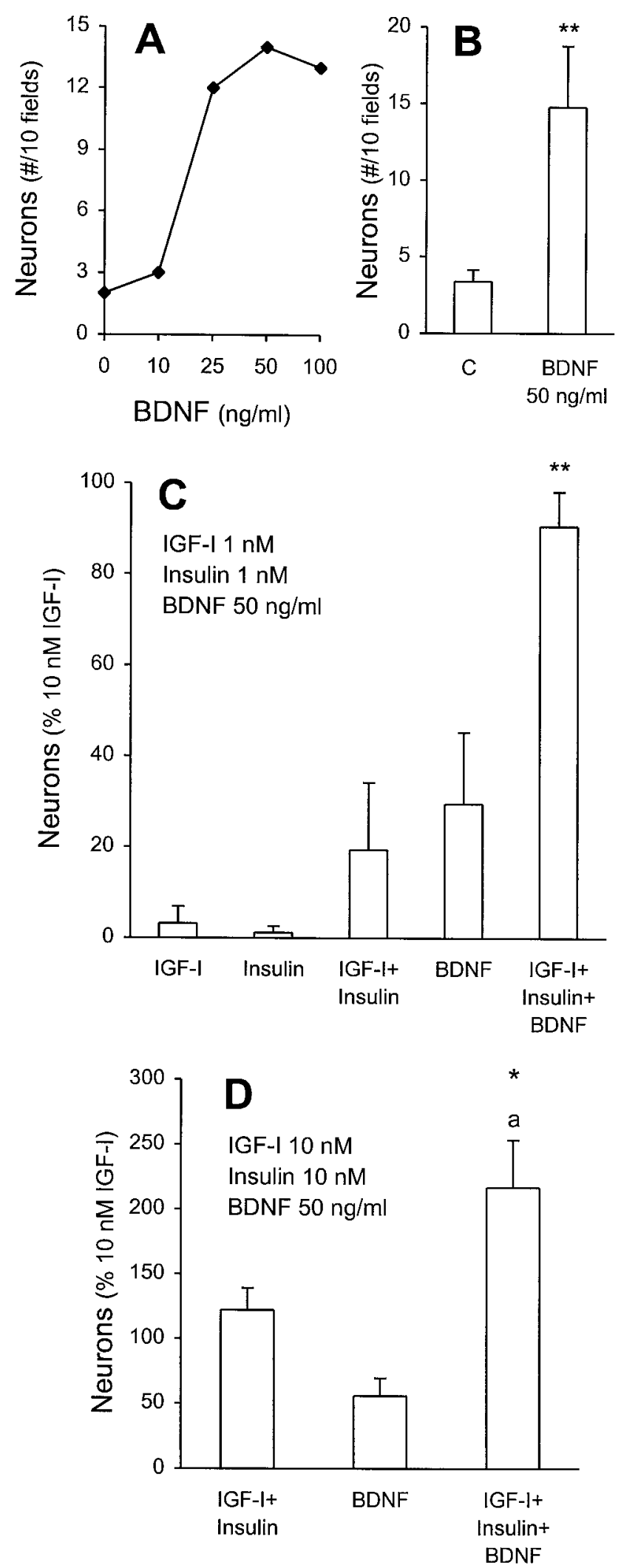

icantly different (IGF-I plus insulin $=642 \pm 44$ cells $/ 10$ fields; IGF-I plus insulin plus BDNF $=780 \pm 121$ cells $/ 10$ fields; $n=5$ ). Taken together, these findings suggest that there are at least two populations of neuronal precursors that are differentially responsive to IGF-I plus insulin and BDNF.

We next asked whether these two populations could be distinguished by neurotransmitter phenotype. In a previous study we found that all neurons induced to differentiate in the presence of BDNF colocalized GABA and substance P (Ahmed et al., 1995). This was confirmed in the present study, whereby close to $100 \%$ of the BDNF-generated neurons were GABA-immunoreactive (Fig. $7 C$ ). On the other hand, of those neurons generated in the presence of IGF-I alone, 35\% were GABAergic, although the remainder were not. Attempts to identify the neurotransmitter phenotype by testing antibodies that recognize tyrosine hydroxylase, calbindin, or parvalbumin were unsuccessful. Nevertheless, these data further support the contention that IGF-I and BDNF may act on two distinct populations of stem cell-derived neuronal precursors.

\section{DISCUSSION}

The overall objective of this work was to ask whether IGF-I influences the differentiation of EGF-responsive stem cellgenerated neuronal precursors. Three conclusions may be drawn as a result of our findings. First, IGF-I, acting via its cognate receptor, promotes the differentiation (and not proliferation or survival) of postmitotic neuronal precursors. Second, insulin, likely acting via its cognate receptor, appears to recruit (in the presence of IGF-I) a more primitive precursor, e.g., upstream and mitotically active. Finally, the actions of IGF-I can be distinguished from those of BDNF, in that BDNF can act alone to differentiate a separate population of postmitotic neuronal precursors. Each of these conclusions will be discussed in turn.

The first major finding in this study was that in absence of IGF peptides virtually no neurons were present in our cultures of dissociated EGF-generated stem cell progeny and that increasing concentrations of either IGF-I, insulin, or IGF-II could induce similar increases in the number of differentiated neurons. Moreover, the magnitude of the increased neuronal number was eightto 40 -fold. The rank order of potency of the three growth factors (IGF-I > IGF-II > insulin) suggests action at a single receptor,

\footnotetext{
$\leftarrow$

Figure 6. Independent and cooperative actions of BDNF and IGF-I plus insulin in neuronal differentiation. $A$, EGF-generated precursors were cultured without IGF-I or insulin and with increasing concentrations of BDNF for 7 DIV. A representative experiment illustrates a dosedependent increase in neuron numbers (total cell number was unaffected; data not shown). $B$, Cumulative data for saturating concentrations (50 $\mathrm{ng} / \mathrm{ml}$ ) of BDNF illustrate a significant three- to fourfold increase in neurons relative to control (** $p<0.01 ; n=8$ independent cultures). $C$, BDNF potentiates the actions of low concentrations of insulin and IGF-I. As described in the legend to Figure 3 and Materials and Methods, the number of neurons generated by 7 DIV incubation with $10 \mathrm{~nm}$ IGF-I (15-50 $\beta$-tubulin-immunoreactive neurons within 600-900 cells) serves as $100 \%$. The number of neurons generated by the combined actions of $1 \mathrm{nM}$ insulin plus $1 \mathrm{nM}$ IGF-I plus $50 \mathrm{ng} / \mathrm{ml}$ BDNF was significantly greater than either insulin plus IGF-I or BDNF alone $\left({ }^{* *} p=0.02\right)$. When the action of BDNF was subtracted, the resultant insulin plus IGF-I response was 3.85 -fold greater than that generated in its absence $(p<0.05)$. $D$, BDNF acts on a distinct population of neuronal precursors. Effects of $10 \mathrm{~nm}$ IGF-I and/or insulin were tested with $50 \mathrm{ng} / \mathrm{ml}$ of BDNF. An additive action of IGF-I and insulin with BDNF was observed. ${ }^{*} p=0.03$ in comparison to $10 \mathrm{nM}$ IGF-I; ${ }^{\mathrm{a}} p<0.01$ in comparison to BDNF or to IGF-I coincubated with insulin ( $n=5$ independent cultures).
} 

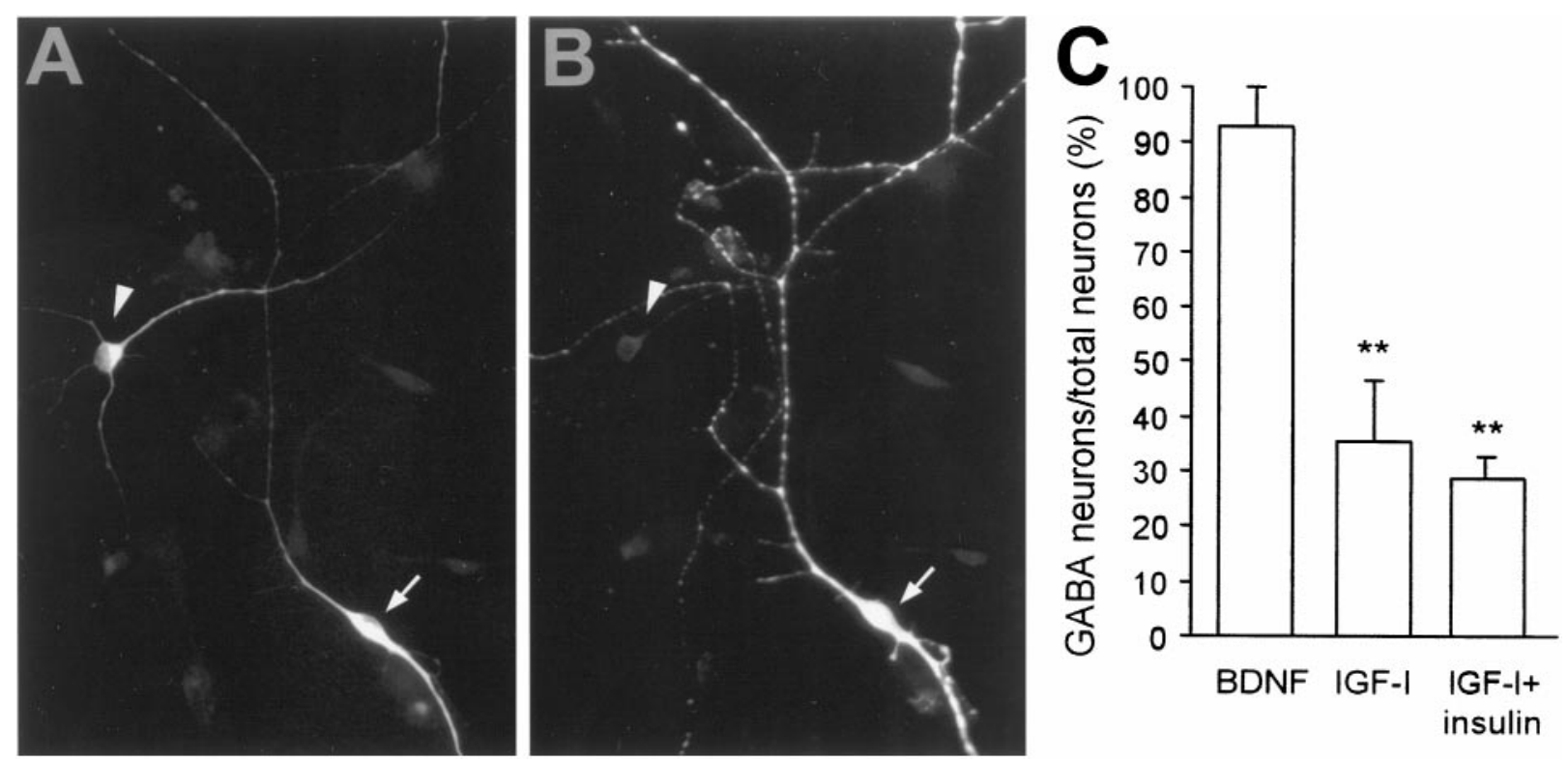

Figure 7. BDNF induces differentiation of GABAergic neurons, whereas IGF-I-generated neurons are principally non-GABAergic. $A$, $B$, IGF-I generated a population of non-GABAergic neurons. The arrow illustrates a cell that is immunoreactive for $\beta$-tubulin $(A)$, but not for GABA $(B$, arrowhead). $C$, Quantitative analysis of the GABAergic neurons present after differentiation by BDNF, IGF-I, or IGF-I plus insulin. The results reveal that BDNF generated only GABAergic neurons, whereas IGF-I-generated and IGF-I plus insulin-generated neurons were principally non-GABAergic. In all, 100-120 neurons were examined per condition and within each experiment $(n=3) ; * *<0.01$.

the IGF-I receptor (LeRoith et al., 1993). That an IGF-I receptor should be present on neuronal precursors is not surprising, given the evidence for the receptor mRNA or binding sites on CNS neurons (Shemer et al., 1987; Bondy, 1991) and for IGF-Imediated neuronal signal transduction (Heidenreich, 1993; Robinson et al., 1994). What is surprising and novel, perhaps, is that the activation of this receptor results in a single response, promoting the differentiation of a postmitotic neuronal precursor. The fact that the complete differentiation response can be induced in as little as $2 \mathrm{hr}$ of exposure suggests that IGF-I initiates a differentiation program. Such an induction was described recently for platelet-derived growth factor (PDGF) action on primary cortical neuronal precursors (Williams et al., 1997). PDGF similarly was found to induce neuronal differentiation in as little as $2 \mathrm{hr}$ of exposure, a process that was dependent on mRNA synthesis. In preliminary studies we recently found that a $2 \mathrm{hr}$ stimulation by IGF-I was able to induce the expression of the POU-III homeodomain containing transcription factor $\mathrm{Brn} 4$ as well as the trkB mRNAs (Y. Arsenijevic, T. Shimazaki, and S. Weiss, unpublished data). Whether the expression of these mRNAs is required for neuronal differentiation is currently under investigation. Moreover, the continued differentiation in the absence of IGF-I (after the $2 \mathrm{hr}$ exposure), coupled with the ability to delay administration for up to $5 \mathrm{~d}$ (and still evoke an almost complete response), suggests that IGF-I is not required as a long-term survival factor for neuronal precursors. This is in contrast to the apparent requirement for IGF-I as a survival factor for neuroepithelial cells as well as for cortical, mesencephalic dopaminergic, and cerebellar neurons (Aizenman and de Vellis, 1987; Drago et al., 1991; Beck et al., 1993; Torres-Aleman et al., 1994). Of those studies, only that of Drago and colleagues (1991) truly established a requirement for IGF-I for cell survival, whereas the results of the latter studies could be accounted for easily by an action of IGF-I on differentiation of postmitotic neuronal precursors. Of course, one could argue that in the absence of differentiation a neuroblast/neuronal precursor ultimately might die. Either interpretation could serve to explain the reduction in certain populations of central neurons in IGF-I null mutation mice (Beck et al., 1995).

The lack of BrdU incorporation in the majority of neurons detected in the presence of IGF-I suggests that IGF-I is not a mitogen for these precursors, as it clearly is for sympathetic neuroblasts (DiCicco-Bloom and Black, 1988; Zackenfels et al., 1995). Moreover, the lack of BrdU incorporation also implies that IGF-I likely exerts its actions on undifferentiated neural precursors that already are committed to the neuronal lineage. Generally, it is accepted that multipotential cells are mainly mitotically active (for review, see Barbe, 1996) and that phenotype change likely requires being close to S phase (McConnell, 1995). Consequently, the closer a cell is to its final fate, the less sensitive it is to signals that can modify that fate (Levitt et al., 1993). Had IGF-I acted as a commitment factor, one would have expected a larger proportion (relative to control) of the neurons to have incorporated BrdU. This was clearly not the case. This is in contrast to the laminin-dependent IGF-I-stimulated production of neurons from avian E5 retinal neuroepithelial cells (Frade et al., 1996). All of the neurons produced in the presence of IGF-I in that study were newly generated, suggesting that IGF-I was acting as a commitment factor. In our study the coincubation of insulin and IGF-I was synergistic and could be attributable to the recruitment of uncommitted cells to the neuronal lineage. In the presence of insulin plus IGF-I, the numbers of BrdUimmunoreactive neurons increased to close to $50 \%$, as compared with $25 \%$ with IGF-I or under control conditions. Moreover, BrdU-immunoreactive neurons could account entirely for the increased numbers of neurons that were generated by coactivation. The present results show clearly that insulin (in the presence of IGF-I) acts on a more primitive, mitotically active precursor in the neuronal lineage, but this study cannot discern whether insulin plus IGF-I is mitogenic for a neuronal precursor or whether 


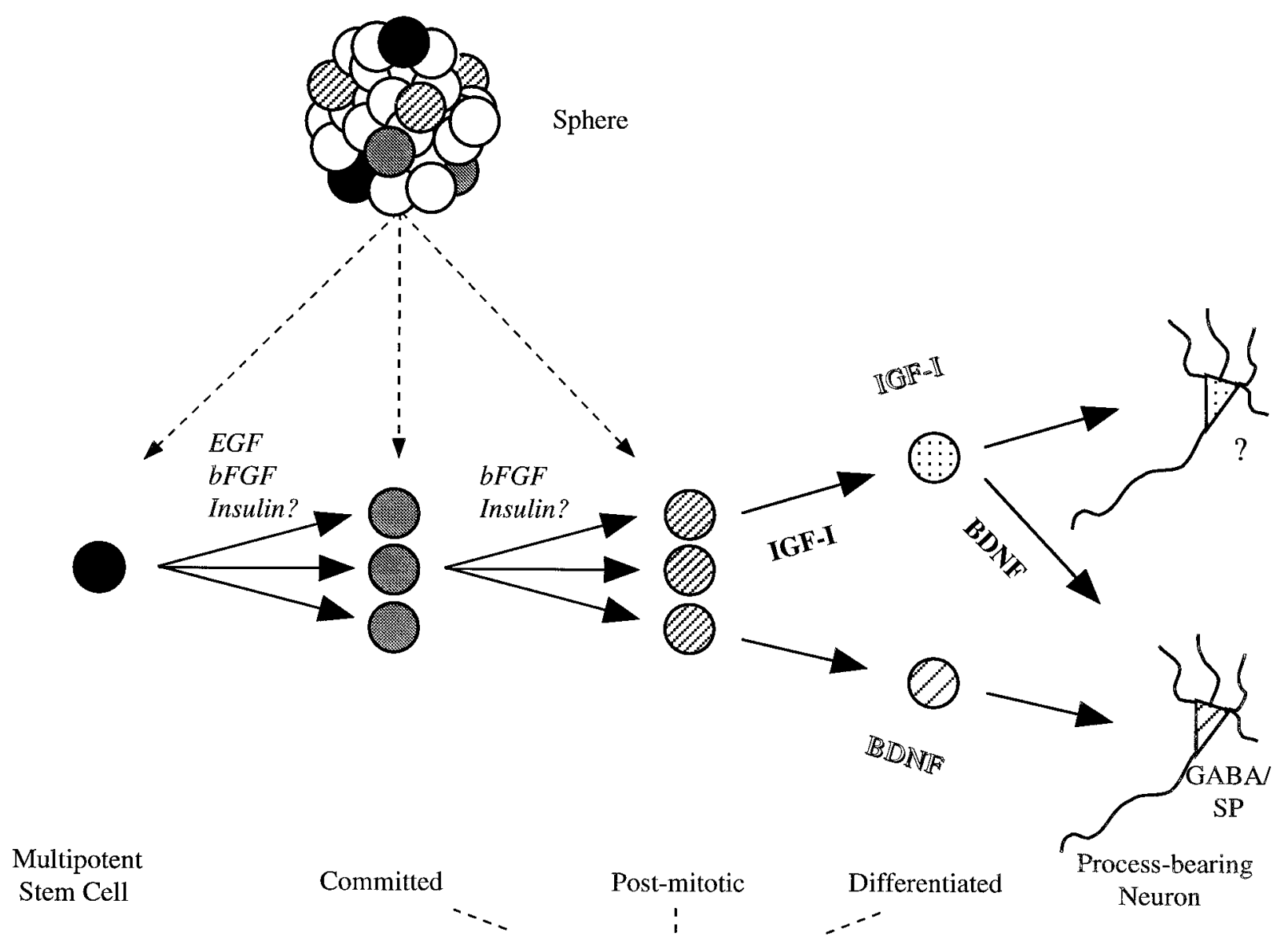

Neuronal Precursors

Figure 8. A model for neurogenesis by multipotent stem cells in vitro. Our working hypothesis is that multipotent stem cells produce neurons in four steps during which neuron number and differentiation are regulated. Both EGF and bFGF induce multipotent stem cells to proliferate. Basic FGF can stimulate committed neuronal precursors (e.g., neuron/astrocyte or neuron only), which are derived from multipotent stem cells, to produce neurons. In either case, insulin may act to recruit multipotential or bipotential precursors to a postmitotic neuronal fate. Subsequently, two possible models (lineage model in italic type and birthdate model in bold type) may serve to explain how IGF-I and BDNF act to induce the differentiation of postmitotic neuronal precursors. See Discussion for details of the two models.

insulin recruits uncommitted mitotically active cells to the neuronal lineage; these are, in turn, differentiated by IGF-I. Clonal analysis, with both sequential and cooperative application of insulin and IGF-I, will be required to distinguish between these possibilities. Nevertheless, reports of insulin regulation of neuroepithelial cell number (De la Rosa et al., 1994) and the recent identification of a NeuroD site on the insulin gene promoter (Lee et al., 1995; Naya et al., 1995) support a role for insulin in programs leading to neuronal differentiation.

In a previous study we found that BDNF was a differentiation factor (Ahmed et al., 1995) for the same CNS stem cell-derived neuronal precursors studied here. In that study, which used a high insulin concentration ( $4 \mu \mathrm{M}$; that would activate both insulin and IGF receptors maximally), BDNF further increased the number of differentiated neurons without any apparent proliferation or survival actions. BDNF actions differed from those of IGF-I in that short exposures, e.g., $48 \mathrm{hr}$, were not sufficient to induce the differentiation response. In the present study we found that BDNF could induce a small population of neuronal precursors to differentiate in the absence of any IGF-I or insulin. This suggests that BDNF likely acts on a separate population of neuronal precursors. Yet BDNF and IGF-I both (1) use tyrosine kinase receptors (Kasuga et al., 1982; Klein et al., 1989, 1991; Cheatham and Khan, 1995; LeRoith et al., 1995), (2) activate p21ras as part of their signal transduction $(\mathrm{Ng}$ and Shooter, 1993; Robinson et al., 1994), and (3) support the survival of mesencephalic dopamine and motor neurons (Beck et al., 1993; Li et al., 1994). Thus, it is reasonable to suggest that BDNF and IGF-I may cooperate on the same populations of neuronal precursors. Indeed, our results support both scenarios. First, we showed that when low concentrations of IGF-I and insulin were coincubated with maximal concentrations of BDNF, the resultant response was more than additive. This suggested either that BDNF was potentiating the IGF-I plus insulin response or vice versa. Thus, we used saturating concentrations of IGF-I plus insulin, together with $\mathrm{BDNF}$, and found the resultant response completely additive. If the BDNF response was amenable to potentiation, we still should have observed a more than additive response. Taken together with the fact that BDNF actions can occur in the absence of either insulin or IGF-I, we propose that BDNF can (1) potentiate the actions of IGF-I plus insulin to the maximum they would achieve via complete activation of their cognate receptors and (2) 
act on a separate population of neuronal precursors that do not require IGF-I plus insulin.

How might insulin, IGF-I, and BDNF operate in CNS neurogenesis in vivo? Our in vitro investigations raise several interesting possibilities. We have postulated two models that could account for the apparently different populations that respond to IGF-I plus insulin (potentiated by BDNF) and to BDNF alone. These are illustrated as part of our working model of neurogenesis from EGF-responsive stem cells in Figure 8. Our contentions for the roles for EGF and bFGF on mitotically active multipotent and committed neuronal precursors are based on our previous clonal analyses (Reynolds et al., 1992; Vescovi et al., 1993; Reynolds and Weiss, 1996) and those of others (Gritti et al., 1996). The results of this study suggest that insulin may act to recruit either multipotent stem cells or bipotential neuronal precursors directly to the postmitotic neuronal fate. Subsequently, two models may explain the actions of IGF-I and BDNF on the differentiation of the postmitotic neuronal precursors. In the first model, the "lineage" model (in italic type), two phenotypically distinct populations generated by the EGF-responsive precursor have differential requirements for IGF-I (plus insulin) or for BDNF. In support of this model are the data whereby we examined the neuronal phenotype of the IGF-I (IGF-I plus insulin) and BDNFresponsive populations. Confirming the results of our previous study (Ahmed et al., 1995), virtually all of the BDNF-responsive neurons contained GABA, whereas significantly fewer of those that were dependent on IGF-I (or IGF-I plus insulin) contained the amino acid transmitter. The phenotype of the nonGABAergic populations has not been determined. Of course, one could argue that perhaps this population has yet to express its phenotype and thus would support the second model (in bold type), the "birthdate" model. In this scenario, neuronal precursors first would be dependent on IGF-I for differentiation, followed by BDNF. BDNF previously has been termed a late differentiation factor for cerebellar granule cells (Gao et al., 1995). Several lines of evidence support this model. First, as discussed above, the minimal time necessary for differentiation is $2 \mathrm{hr}$ for IGF-I and $>48 \mathrm{hr}$ for BDNF. Second, twice as many ( $\sim 25 \%$ ) IGF-I-responsive precursors incorporated BrdU than did those that were BDNF-responsive. This suggests that the BDNF-responsive neuronal precursors are further downstream (further from $\mathrm{S}$ phase). Moreover, it suggests that precursors develop BDNF responsiveness in the absence of IGF-I and that IGF-I may enhance the onset of the response. In fact, preliminary data from our lab have found that a $2 \mathrm{hr}$ exposure of stem cell progeny to IGF-I resulted in an immediate upregulation of the catalytic domain-containing trkB transcript (Y. Arsenijevic, T. Shimazaki and S. Weiss, unpublished observations). Taken together, these findings support the contention that, although not required, IGF-I and BDNF may act in a sequential manner as early and later differentiation signals, with a feed-forward (and possible feed-backward) regulation of receptor expression. Ongoing experimentation examining birthdates and the sequential stimulation of growth factor receptors should serve to reconcile these two models of neuronal differentiation.

In addition to new basic concepts regarding the actions of IGF-I and BDNF on the differentiation of neuronal precursors, our results also raise some interesting practical considerations. IGF-I and BDNF recently have been demonstrated to have important neurotrophic actions in both motor neuron and striatal neurons (Hughes et al., 1993; Neff et al., 1993; Li et al., 1994; Ventimiglia et al., 1995; Nakao et al., 1996). If the synergistic action among insulin, IGF-I, and BDNF operates on postmitotic neurons in vivo, lower (and thus likely less toxic) concentrations of these factors could be administered in combination for therapeutic intervention in disorders such as amyotrophic lateral sclerosis and Huntington's disease (Adem et al., 1994; Dore et al., 1997).

\section{REFERENCES}

Adem A, Ekblom J, Gillberg P-G (1994) Growth factor receptors in amyotrophic lateral sclerosis. Mol Neurobiol 9:225-231.

Ahmed S, Reynolds BA, Weiss S (1995) BDNF enhances the differentiation but not the survival of CNS stem cell-derived neuronal precursors. J Neurosci 15:5765-5778.

Aizenman Y, de Vellis J (1987) Brain neurons develop in a serum and glial free environment: effects of transferrin, insulin, insulin-like growth factor-I, and thyroid hormone on neuronal survival, growth, and differentiation. Brain Res 406:32-42.

Barbe MF (1996) Tempting fate and commitment in the developing forebrain. Neuron 16:1-4.

Bartlett WP, Li X-S, Williams M, Benkovic S (1991) Localization of insulin-like growth factor-I mRNA in murine central nervous system during postnatal development. Dev Biol 147:239-250.

Bassas L, Girbau M, Lesniak MA, Roth J, de Pablo F (1989) Development of receptors for insulin and insulin-like growth factor-I in head and brain of chick embryos: autoradiographic localization. Endocrinology 125:2320-2326.

Beck KD, Knüsel B, Hefti F (1993) The nature of the trophic action of brain-derived neurotrophic factor, des(1-3)-insulin-like growth factor-I, and basic fibroblast growth factor on mesencephalic dopaminergic neurons developing in culture. Neuroscience 52:855-866.

Beck K, Powell-Braxton L, Widmer H-R, Valverde J, Hefti F (1995) IGF-1 gene disruption results in reduced brain size, CNS hypomyelination, and loss of hippocampal granule and striatal parvalbumincontaining neurons. Neuron 14:717-730.

Bondy CA (1991) Transient IGF-I gene expression during the maturation of functionally related central projection neurons. J Neurosci 11:3442-3455.

Bondy CA, Werner H, Roberts Jr CT, LeRoith D (1990) Cellular pattern of insulin-like growth factor-I (IGF-I) and type I IGF receptor gene expression in early organogenesis: comparison with IGF-II gene expression. Mol Endocrinol 4:1386-1398.

Bondy CA, Werner H, Roberts Jr CT, LeRoith D (1992) Cellular pattern of type I insulin-like growth factor receptor gene expression during maturation of the rat brain: comparison with insulin-like growth factors I and II. Neuroscience 4:909-923.

Caroni P, Grandes P (1990) Nerve sprouting in innervated adult skeletal muscle induced by exposure to elevated levels of insulin-like growth factors. J Cell Biol 110:1307-1317.

Cheatham B, Kahn CR (1995) Insulin action and the insulin signaling network. Endocr Rev 16:117-142.

Craig CG, Tropepe V, Morshead CM, Reynolds BA, Weiss S, van der Kooy D (1996) In vivo growth factor expansion of endogenous subependymal neural precursor cell populations in the adult mouse brain. J Neurosci 16:2649-2658.

de la Rosa EJ, Bondy CA, Hernandez-Sanchez C, Wu X, Zhou J, Lopez-Carranza A, Scavo LM, de Pablo F (1994) Insulin and insulinlike growth factor system components gene expression in the chicken retina from early neurogenesis until late development and their effect on neuroepithelial cells. Eur J Neurosci 6:1801-1810.

Devaskar SU, Singh BS, Carnaghi LR, Rajakumar PA, Giddings SJ (1993) Insulin II gene expression in rat central nervous system. Regul Pept 48:55-63.

DiCicco-Bloom E, Black I (1988) Insulin growth factors regulate the mitotic cycle in cultured rat sympathetic neuroblasts. Proc Natl Acad Sci USA 85:4066-4070.

Dore S, Kar S, Quirion R (1997) Rediscovering an old friend, IGF-I: potential use in the treatment of neurodegenerative diseases. Trends Neurosci 20:326-331.

Drago J, Murphy M, Carroll SM, Harvey RP, Bartlett PF (1991) Fibroblast growth factor-mediated proliferation of central nervous system precursors depends on endogenous production of insulin-like growth factor-I. Proc Natl Acad Sci USA 88:2199-2203.

Frade JM, Marti E, Bovolenta P, Rodriguez-Peña MA, Perez-Garcia D, Rohrer H, Edgar D, Rodriguez-Tébar A (1996) Insulin-like growth 
factor-I stimulates neurogenesis in chick retina by regulating expression of the $\alpha 6$ integrin subunit. Development 122:2497-2506.

Gao WQ, Zheng JL, Karihaloo M (1995) Neurotrophin-4/5 (NT-4/5) and brain-derived neurotrophic factor (BDNF) act at later stage of cerebellar granule cell differentiation. J Neurosci 15:2656-2667.

Garcia-Segura LM, Perez J, Pons S, Rejas MT, Torres-Aleman I (1991) Localization of insulin-like growth factor-I (IGF-I)-like immunoreactivity in the developing and adult rat brain. Brain Res 560:167-174.

Garofalo RS, Rosen OM (1988) Tissue localization of Drosophila melanogaster insulin receptor during development. Mol Cell Biol 8:1638-1647.

Gritti A, Parati EA, Cova L, Frolichsthal P, Galli R, Wanke E, Faravelli L, Morassutti DJ, Roisen F, Nickel DD, Vescovi AL (1996) Multipotential stem cells from the adult mouse brain proliferate and self-renew in response to basic fibroblast growth factor. J Neurosci 16:1091-1100.

Heidenreich KA (1993) Insulin and IGF-I receptor signaling in cultured neurons. Ann NY Acad Sci 692:72-88.

Hughes RA, Sendtner M, Thoenen H (1993) Members of several gene families influence survival of rat motoneurons in vitro and in vivo. J Neurosci Res 36:663-671.

Ishii DN (1995) Implication of insulin-like growth factors in the pathogenesis of diabetic neuropathy. Brain Res Rev 20:47-67.

Kar S, Chabot J-G, Quirion R (1993) Quantitative autoradiographic localization of $\left[{ }^{125} \mathrm{I}\right]$ insulin-like growth factor-I, [ $\left.{ }^{125} \mathrm{I}\right]$ insulin-like growth factor-II, and [ $\left.{ }^{125} \mathrm{I}\right]$ insulin receptor binding sites in developing and adult rat brain. J Comp Neurol 333:375-397.

Kasuga M, Karlsson FA, Kahn CR (1982) Insulin stimulates the phosphorylation of the 95,000 dalton subunit of its own receptor. Science 215:185-187.

Klein R, Parada LF, Coulier F, Barbacid M (1989) trkB, a novel tyrosine protein kinase receptor expressed during mouse neural development. EMBO J 8:3701-3709.

Klein R, Nanduri V, Jing S, Lamballe F, Tapley P, Bryant S, CordonCardo C, Jones KR, Reichardt LF, Barbacid M (1991) The trkB tyrosine protein kinase is a receptor for brain-derived neurotrophic factor and neurotrophin-3. Cell 66:395-403.

Knusel B, Michel PP, Schwaber JS, Hefti F (1990) Selective and nonselective stimulation of central cholinergic and dopaminergic development in vitro by nerve growth factor, basic fibroblast growth factor, epidermal growth factor, insulin, and the insulin-like growth factor I and II. J Neurosci 10:558-570.

Lee JE, Hollenberg SM, Snider L, Turner DL, Lipnick N, Weintraub H (1995) Conversion of Xenopus ectoderm into neurons by neuroD, a basic helix-loop-helix protein. Science 268:836-844.

LeRoith D, Lowe Jr WL, Shemer J, Raizada M, Ota A (1988) Development of brain insulin receptors. Int J Biochem 20:225-230.

LeRoith D, Werner H, Faria TN, Kato H, Adamo M, Roberts Jr CT (1993) Insulin-like growth factor receptors. Ann NY Acad Sci 692:23-32.

LeRoith D, Werner H, Beitner-Johnson D, Roberts Jr CT (1995) Molecular and cellular aspects of the insulin-like growth factor-I receptor. Endocr Rev 16:143-163.

Levitt P, Ferri RT, Barbe MF (1993) Progressive acquisition of cortical phenotypes as a mechanism for specifying the developing cerebral cortex. Perspect Dev Neurol 1:65-74.

Li L, Oppenheim RW, Lei M, Houenou LJ (1994) Neurotrophic agents prevent motoneuron death following sciatic nerve section in the neonatal mouse. J Neurobiol 25:759-766.

McConnell SK (1995) Constructing the cerebral cortex: neurogenesis and fate determination. Neuron 15:761-768.

Mill JF, Chao MV, Ishii DN (1985) Insulin, insulin-like growth factor-II, and nerve growth factor effects on tubulin mRNA levels and neurites formation. Proc Natl Acad Sci USA 82:7126-7130.
Morshead CM, Reynolds BA, Craig CG, McBurney MW, Staines WA, Morassutti D, Weiss S, van der Kooy D (1994) Neural stem cells in the adult mammalian forebrain: a relatively quiescent subpopulation of subependymal cells. Neuron 13:1071-1082.

Nakao N, Odin P, Lindvall O, Brundin P (1996) Differential trophic effects of basic fibroblast growth factor, insulin-like growth factor-I, and neurotrophin-3 on striatal neurons in culture. Exp Neurol 138:144-157.

Naya FJ, Stellrecht CMM, Tsai M-J (1995) Tissue-specific regulation of the insulin gene by a novel basic helix-loop-helix transcription factor. Genes Dev 9:1009-1019.

Neff NT, Prevette D, Houenou LJ, Lewis ME, Glicksman MA, Yin W-W, Oppenheim W (1993) Insulin-like growth factors: putative muscle-derived trophic agents that promote motoneuron survival. J Neurobiol 24:1578-1588.

Ng NFL, Shooter EM (1993) Activation of p21ras by nerve growth factor in embryonic sensory neurons and PC12 cells. J Biol Chem 268:25329-25333.

Petruzelli L, Herrera R, Arenas-Garcia RA, Fernandez R, Birnbaum MJ, Rosen OM (1986) Isolation of a Drosophila genomic sequence homologous to the kinase domain of the human insulin receptor and detection of the phosphorylated Drosophila receptor with an antipeptide antibody. Proc Natl Acad Sci USA 83:4710-4714.

Reynolds BA, Weiss S (1992) Generation of neurons and astrocytes from isolated cells of the adult mammalian central nervous system. Science 255:1707-1710.

Reynolds BA, Weiss S (1996) Clonal and population analyses demonstrate that an EGF-responsive mammalian embryonic CNS precursor is a stem cell. Dev Biol 175:1-13.

Reynolds BA, Tetzlaff W, Weiss S (1992) A multipotent EGFresponsive striatal embryonic progenitor cell produces neurons and astrocytes. J Neurosci 12:4565-4574.

Robinson LJ, Leitner W, Draznin B, Heidenreich KA (1994) Evidence that p21ras mediates the neurotrophic effects of insulin-like growth factor-I in chick forebrain neurons. Endocrinology 135:2568-2573.

Shemer J, Raizada MK, Masters BA, Ota A, LeRoith D (1987) Insulinlike growth factor-I receptors in neuronal and glial cells. J Biol Chem 262:7693-7699.

Toran-Allerand CD, Bentham W, Miranda RC, Anderson JP (1991) Insulin influences astroglial morphology and glial fibrillary acidic protein (GFAP) expression in organotypic cultures. Brain Res 558:296-304.

Torres-Aleman I, Pons S, Arevalo MA (1994) The insulin-like growth factor-I system in the rat cerebellum: developmental regulation and role in neuronal survival and differentiation. J Neurosci Res 39:117-126.

Ventimiglia R, Mather PE, Jones BE, Lindsay RM (1995) The neurotrophins BDNF, NT-3, and NT-4/5 promote survival and morphological and biochemical differentiation of striatal neurons in vitro. Eur J Neurosci 7:213-222.

Vescovi AL, Reynolds BA, Fraser DD, Weiss S (1993) BFGF regulates the proliferative fate of unipotent (neuronal) and bipotent (neuronal/ astroglial) EGF-generated CNS progenitor cells. Neuron 11:951-966.

Weiss S, Reynolds BA, Vescovi AL, Morshead C, Craig CG, van der Kooy D (1996) Is there a neural stem cell in the mammalian forebrain? Trends Neurosci 19:387-393.

Williams BP, Park JK, Alberta JA, Muhlebach SG, Hwang GY, Roberts TM, Stiles CD (1997) A PDGF-regulated immediate early gene response initiates neuronal differentiation in ventricular zone progenitor cells. Neuron 18:553-562.

Zackenfels K, Oppenheim RW, Rohrer H (1995) Evidence for an important role of IGF-I and IGF-II for the early development of chick sympathetic neurons. Neuron 14:731-741. 